\title{
NADPH oxidases in GtoPdb v.2021.3
}

Albert van der Vliet ${ }^{1}$

1. University of Vermont, USA

\begin{abstract}
The two DUOX enzymes were originally identified as participating in the production of hydrogen peroxide as a pre-requisite for thyroid hormone biosynthesis in the thyroid gland [9].

NOX enzymes function to catalyse the reduction of molecular oxygen to superoxide and various other reactive oxygen species (ROS). They are subunits of the NADPH oxidase complex.
\end{abstract}

\section{Contents}

This is a citation summary for NADPH oxidases in the Guide to Pharmacology database (GtoPdb). It exists purely as an adjunct to the database to facilitate the recognition of citations to and from the database by citation analyzers. Readers will almost certainly want to visit the relevant sections of the database which are given here under database links.

GtoPdb is an expert-driven guide to pharmacological targets and the substances that act on them. GtoPdb is a reference work which is most usefully represented as an on-line database. As in any publication this work should be appropriately cited, and the papers it cites should also be recognized. This document provides a citation for the relevant parts of the database, and also provides a reference list for the research cited by those parts. For further details see [4].

Please note that the database version for the citations given in GtoPdb are to the most recent preceding version in which the family or its subfamilies and targets were substantially changed. The links below are to the current version. If you need to consult the cited version, rather than the most recent version, please contact the GtoPdb curators.

\section{Database links}

NADPH oxidases

https://www.guidetopharmacology.org/GRAC/FamilyDisplayForward?familyId=993

Introduction to NADPH oxidases

https://www.guidetopharmacology.org/GRAC/FamilyIntroductionForward?familyId=993

Enzymes

DUOX1(dual oxidase 1)

https://www.guidetopharmacology.org/GRAC/ObjectDisplayForward?objectId=3000

DUOX2(dual oxidase 2)

https://www.guidetopharmacology.org/GRAC/ObjectDisplayForward?objectId=2999

NOX1(NADPH oxidase 1)

https://www.guidetopharmacology.org/GRAC/ObjectDisplayForward?objectId=3001

NOX2(cytochrome b-245 beta chain)

https://www.guidetopharmacology.org/GRAC/ObjectDisplayForward?objectId=3002 NOX3(NADPH oxidase 3)

https://www.guidetopharmacology.org/GRAC/ObjectDisplayForward?objectId=3003 NOX4(NADPH oxidase 4)

https://www.guidetopharmacology.org/GRAC/ObjectDisplayForward?objectId=3004

NOX5(NADPH oxidase 5)

https://www.guidetopharmacology.org/GRAC/ObjectDisplayForward?objectId=3005

\section{References}

1. Aoyama T, Paik YH, Watanabe S, Laleu B, Gaggini F, Fioraso-Cartier L, Molango S, Heitz F, 
Merlot C and Szyndralewiez C et al.. (2012) Nicotinamide adenine dinucleotide phosphate oxidase in experimental liver fibrosis: GKT137831 as a novel potential therapeutic agent. Hepatology 56: 2316-27 [PMID:22806357]

2. Barman SA, Chen F, Su Y, Dimitropoulou C, Wang Y, Catravas JD, Han W, Orfi L, Szantai-Kis C and Keri G et al.. (2014) NADPH oxidase 4 is expressed in pulmonary artery adventitia and contributes to hypertensive vascular remodeling. Arterioscler Thromb Vasc Biol 34: 1704-15 [PMID:24947524]

3. Bedard K and Krause KH. (2007) The NOX family of ROS-generating NADPH oxidases: physiology and pathophysiology. Physiol Rev 87: 245-313 [PMID:17237347]

4. Buneman P, Christie G, Davies JA, Dimitrellou R, Harding SD, Pawson AJ, Sharman JL and Wu Y. (2020) Why data citation isn't working, and what to do about it Database 2020 [PMID:32367113]

5. Bánfi B, Maturana A, Jaconi S, Arnaudeau S, Laforge T, Sinha B, Ligeti E, Demaurex N and Krause KH. (2000) A mammalian H+ channel generated through alternative splicing of the NADPH oxidase homolog NOH-1. Science 287: 138-42 [PMID:10615049]

6. Bánfi B, Molnár G, Maturana A, Steger K, Hegedûs B, Demaurex N and Krause KH. (2001) A $\mathrm{Ca}(2+)$-activated NADPH oxidase in testis, spleen, and lymph nodes. J Biol Chem 276: 37594601 [PMID:11483596]

7. Cheng G, Cao Z, Xu X, van Meir EG and Lambeth JD. (2001) Homologs of gp91phox: cloning and tissue expression of Nox3, Nox4, and Nox5. Gene 269: 131-40 [PMID:11376945]

8. De Deken X, Corvilain B, Dumont JE and Miot F. (2014) Roles of DUOX-mediated hydrogen peroxide in metabolism, host defense, and signaling. Antioxid Redox Signal 20: 2776-93 [PMID:24161126]

9. De Deken X, Wang D, Many MC, Costagliola S, Libert F, Vassart G, Dumont JE and Miot F. (2000) Cloning of two human thyroid cDNAs encoding new members of the NADPH oxidase family. J Biol Chem 275: 23227-33 [PMID:10806195]

10. Donkó A, Ruisanchez E, Orient A, Enyedi B, Kapui R, Péterfi Z, de Deken X, Benyó Z and Geiszt M. (2010) Urothelial cells produce hydrogen peroxide through the activation of Duox1. Free Radic Biol Med 49: 2040-8 [PMID:21146788]

11. Dupuy C, Ohayon R, Valent A, Noël-Hudson MS, Dème D and Virion A. (1999) Purification of a novel flavoprotein involved in the thyroid NADPH oxidase. Cloning of the porcine and human cdnas. J Biol Chem 274: 37265-9 [PMID:10601291]

12. Durand N and Storz P. (2017) Targeting reactive oxygen species in development and progression of pancreatic cancer. Expert Rev Anticancer Ther 17: 19-31 [PMID:27841037]

13. Edens WA, Sharling L, Cheng G, Shapira R, Kinkade JM, Lee T, Edens HA, Tang X, Sullards C and Flaherty DB et al.. (2001) Tyrosine cross-linking of extracellular matrix is catalyzed by Duox, a multidomain oxidase/peroxidase with homology to the phagocyte oxidase subunit gp91phox. J Cell Biol 154: 879-91 [PMID:11514595]

14. El Hassani RA, Benfares N, Caillou B, Talbot M, Sabourin JC, Belotte V, Morand S, Gnidehou S, Agnandji D and Ohayon R et al.. (2005) Dual oxidase2 is expressed all along the digestive tract. Am J Physiol Gastrointest Liver Physiol 288: G933-42 [PMID:15591162]

15. Freund-Michel V, Guibert C, Dubois M, Courtois A, Marthan R, Savineau JP and Muller B. (2013) Reactive oxygen species as therapeutic targets in pulmonary hypertension. Ther Adv Respir Dis 7: 175-200 [PMID:23328248]

16. Gaggini F, Laleu B, Orchard M, Fioraso-Cartier L, Cagnon L, Houngninou-Molango S, Gradia A, Duboux G, Merlot C and Heitz F et al.. (2011) Design, synthesis and biological activity of original pyrazolo-pyrido-diazepine, -pyrazine and -oxazine dione derivatives as novel dual Nox4/Nox1 inhibitors. Bioorg Med Chem 19: 6989-99 [PMID:22041175]

17. Geiszt M, Witta J, Baffi J, Lekstrom K and Leto TL. (2003) Dual oxidases represent novel hydrogen peroxide sources supporting mucosal surface host defense. FASEB J 17: 1502-4 [PMID:12824283]

18. Ghatak S, Hascall VC, Markwald RR, Feghali-Bostwick C, Artlett CM, Gooz M, Bogatkevich GS, Atanelishvili I, Silver RM and Wood J et al.. (2017) Transforming growth factor $\beta 1$ (TGFß1)induced CD44V6-NOX4 signaling in pathogenesis of idiopathic pulmonary fibrosis. $J$ Biol Chem 292: 10490-10519 [PMID:28389561]

19. Guzik TJ and Harrison DG. (2006) Vascular NADPH oxidases as drug targets for novel antioxidant strategies. Drug Discov Today 11: 524-33 [PMID:16713904]

20. Habibovic A, Hristova M, Heppner DE, Danyal K, Ather JL, Janssen-Heininger YM, Irvin CG, Poynter ME, Lundblad LK and Dixon AE et al.. (2016) DUOX1 mediates persistent epithelial EGFR activation, mucous cell metaplasia, and airway remodeling during allergic asthma. JCI Insight 1: e88811 [PMID:27812543]

21. Hecker L, Vittal R, Jones T, Jagirdar R, Luckhardt TR, Horowitz JC, Pennathur S, Martinez FJ and Thannickal VJ. (2009) NADPH oxidase-4 mediates myofibroblast activation and fibrogenic responses to lung injury. Nat Med 15: 1077-81 [PMID:19701206]

22. Hirakawa S, Saito R, Ohara H, Okuyama R and Aiba S. (2011) Dual oxidase 1 induced by Th2 
cytokines promotes STAT6 phosphorylation via oxidative inactivation of protein tyrosine phosphatase 1B in human epidermal keratinocytes. J Immunol 186: 4762-70 [PMID:21411736]

23. Kuroda J, Ago T, Matsushima S, Zhai P, Schneider MD and Sadoshima J. (2010) NADPH oxidase 4 (Nox4) is a major source of oxidative stress in the failing heart. Proc Natl Acad Sci USA 107: 15565-70 [PMID:20713697]

24. Kwon J, Shatynski KE, Chen H, Morand S, de Deken X, Miot F, Leto TL and Williams MS. (2010) The nonphagocytic NADPH oxidase Duox1 mediates a positive feedback loop during $\mathrm{T}$ cell receptor signaling. Sci Signal 3: ra59 [PMID:20682913]

25. Laleu B, Gaggini F, Orchard M, Fioraso-Cartier L, Cagnon L, Houngninou-Molango S, Gradia A, Duboux G, Merlot C and Heitz F et al.. (2010) First in class, potent, and orally bioavailable NADPH oxidase isoform 4 (Nox4) inhibitors for the treatment of idiopathic pulmonary fibrosis. $J$ Med Chem 53: 7715-30 [PMID:20942471]

26. Lambeth JD. (2004) NOX enzymes and the biology of reactive oxygen. Nat Rev Immunol 4: 181-9 [PMID:15039755]

27. Lambeth JD, Krause KH and Clark RA. (2008) NOX enzymes as novel targets for drug development. Semin Immunopathol 30: 339-63 [PMID:18509646]

28. Li Y and Pagano PJ. (2017) Microvascular NADPH oxidase in health and disease. Free Radic Biol Med 109: 33-47 [PMID:28274817]

29. Little AC, Sulovari A, Danyal K, Heppner DE, Seward DJ and van der Vliet A. (2017) Paradoxical roles of dual oxidases in cancer biology. Free Radic Biol Med 110: 117-132 [PMID:28578013]

30. Lu J, Risbood P, Kane Jr CT, Hossain MT, Anderson L, Hill K, Monks A, Wu Y, Antony S and Juhasz A et al.. (2017) Characterization of potent and selective iodonium-class inhibitors of NADPH oxidases. Biochem Pharmacol 143: 25-38 [PMID:28709950]

31. Montezano AC, Dulak-Lis M, Tsiropoulou S, Harvey A, Briones AM and Touyz RM. (2015) Oxidative stress and human hypertension: vascular mechanisms, biomarkers, and novel therapies. Can J Cardiol 31: 631-41 [PMID:25936489]

32. Paravicini TM, Chrissobolis S, Drummond GR and Sobey CG. (2004) Increased NADPH-oxidase activity and Nox4 expression during chronic hypertension is associated with enhanced cerebral vasodilatation to NADPH in vivo. Stroke 35: 584-9 [PMID:14739416]

33. Rada B, Park JJ, Sil P, Geiszt M and Leto TL. (2014) NLRP3 inflammasome activation and interleukin-1 $\beta$ release in macrophages require calcium but are independent of calcium-activated NADPH oxidases. Inflamm Res 63: 821-30 [PMID:25048991]

34. Sato N, Takasaka N, Yoshida M, Tsubouchi K, Minagawa S, Araya J, Saito N, Fujita Y, Kurita Y and Kobayashi K et al.. (2016) Metformin attenuates lung fibrosis development via NOX4 suppression. Respir Res 17: 107 [PMID:27576730]

35. Shiose A, Kuroda J, Tsuruya K, Hirai M, Hirakata H, Naito S, Hattori M, Sakaki Y and Sumimoto H. (2001) A novel superoxide-producing NAD(P)H oxidase in kidney. J Biol Chem 276: 1417-23 [PMID:11032835]

36. Sommer F and Bäckhed F. (2015) The gut microbiota engages different signaling pathways to induce Duox2 expression in the ileum and colon epithelium. Mucosal Immunol 8: 372-9 [PMID:25160818]

37. Sorescu D, Weiss D, Lassègue B, Clempus RE, Szöcs K, Sorescu GP, Valppu L, Quinn MT, Lambeth JD and Vega JD et al.. (2002) Superoxide production and expression of nox family proteins in human atherosclerosis. Circulation 105: 1429-35 [PMID:11914250]

38. van der Vliet A, Danyal K and Heppner DE. (2018) Dual oxidase: a novel therapeutic target in allergic disease. Br J Pharmacol 175: 1401-1418 [PMID:29405261]

39. Xu Q, Kulkarni AA, Sajith AM, Hussein D, Brown D, Güner OF, Reddy MD, Watkins EB, Lassègue B and Griendling KK et al.. (2018) Design, synthesis, and biological evaluation of inhibitors of the NADPH oxidase, Nox4. Bioorg Med Chem 26: 989-998 [PMID:29426628] 